This item was submitted to Loughborough's Research Repository by the author.

Items in Figshare are protected by copyright, with all rights reserved, unless otherwise indicated.

\title{
Understanding prison staff
}

PLEASE CITE THE PUBLISHED VERSION

http://dx.doi.org/10.1177/09500170090230021208

PUBLISHER

Sage $(\subset$ British Sociological Association Publications

VERSION

AM (Accepted Manuscript)

LICENCE

CC BY-NC-ND 4.0

REPOSITORY RECORD

Lumsden, Karen. 2019. “Understanding Prison Staff”. figshare. https://hdl.handle.net/2134/11672. 
This item was submitted to Loughborough's Institutional Repository (https://dspace.lboro.ac.uk/) by the author and is made available under the following Creative Commons Licence conditions.

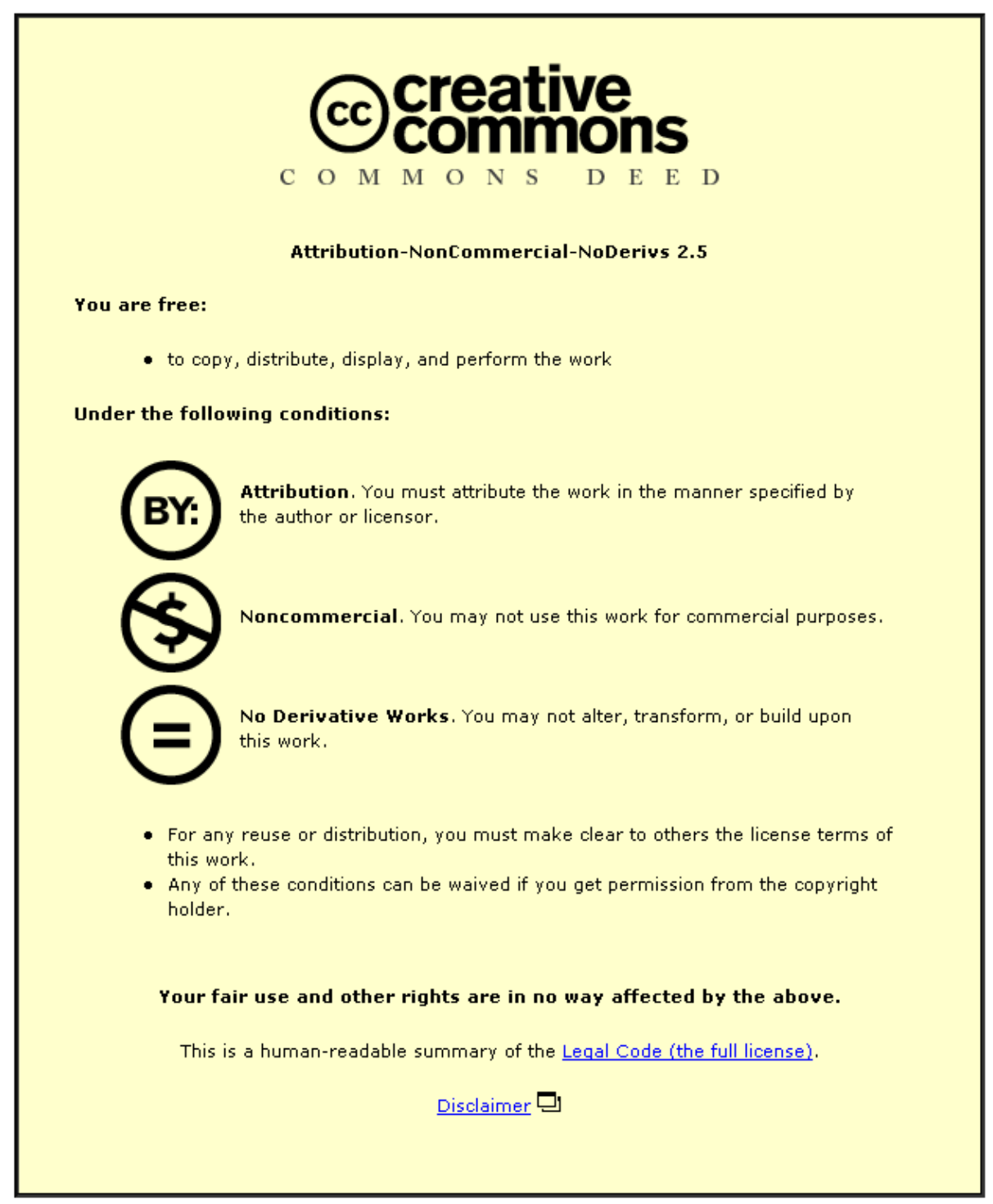

For the full text of this licence, please go to: http://creativecommons.org/licenses/by-nc-nd/2.5/ 


\section{Understanding Prison Staff}

Karen Lumsden, University of Aberdeen

J. Bennett, B. Crewe and A. Wahidin (eds.)

\section{Understanding Prison Staff}

Devon: Willan Publishing, 2008, No price stated hbk, \$44.95 pbk, (ISBN: 9781843922742), $384 \mathrm{pp}$.

Understanding Prison Staff is a collection of essays focusing on the daily lives of individuals working within prisons. The editors argue that the study of prison staff is important because of the effects of prison staff on individuals in custody and the impact of prison work on staff themselves. Prison staff should be viewed as a distinct occupational group worthy of study in their own right (p.2). This collection also contributes towards conceptual issues beyond the realm of criminal justice, such as 'the nature of power, punishment, order, inequality, care, discretion and resistance' (p.2). It demonstrates that considerable progress has been made in the UK in recent years, in terms of furthering our understanding of the occupational world of prison staff.

The book is intended as a starting point for those interested in the subject and as such, the editors make no claims that it is comprehensive or conclusive. The contributors consist of practitioners, research students, established academics and a former prisoner. Each chapter is accompanied by suggestions for further reading and review questions for seminar discussions. They also vary in tone, orientation, political framework, methodological stance, and analytical and descriptive content. The book is organised into five distinct sections: (1) Prisons and Staff Issues; (2) Prison Officers; (3) Prison Managers; (4) Prison Staff; (5) Developing the Human Resources of Prisons.

The first section on 'Prisons and Staff Issues' is comprised of five chapters. Jason Warr begins with an insightful personal reflection on the effects of prison staff on prisoners. King discusses international perspectives on the problem of violence, negligence, and abuse in prisons, and how this might be avoided by various improvements in staff numbers and training. The remaining three chapters are concerned with the experiences of ethnic minority prison officers, the influence of gender in prison officer culture, and the role of prison staff in the public and private sectors. This group of contributions is the least cohesive and at this point it becomes evident that the book's structure would benefit from the inclusion of an outline at the beginning of each section.

The second section 'Prison Officers' discusses industrial relations, cohesion, conflict and order in prison officer culture, and occupational morality. Bennett and Wahidin outline the stereotypical portrayals of industrial relations in prisons while Crawley and Crawley discuss the occupational culture of prison officers. Included here are the ways in which prison officers who are involved in more therapeutic regimes manage a 'spoiled identity' (p.146) and how workers are changed by prison life. In the next chapter Drake argues that forms of order differ depending on the ways in which staff emphasise the policies and control mechanisms at their disposal. The final two chapters in this section focus on human suffering and punishment in prison. Scott's 
chapter is analytically and theoretically illuminating in its discussion of the denial and acknowledgement of prisoner suffering by prison officers, while Sim focuses on the negative impact of prison officer culture on prisoners and those staff who show 'humane empathy' to prisoners (p.189).

In 'Prison Managers', the role of governors, middle, and first-line managers, are discussed in relation to organisational changes in the Prison Service. The fourth section on 'Prison Staff' is concerned with different occupational groups within prison culture such as probation officers, teachers, psychologists, drug workers and health professionals. These sections are particularly relevant in demonstrating that prison staff are not a 'homogenous bloc'. As a group they are 'complex and differentiated', and there are significant distinctions both within and between different staff groupings (p.425). The final section follows on from this by providing an analysis of human resources within prisons.

Due to its broad scope and the variety of contributors, the text is more descriptive than analytical; however it is methodologically and politically diverse. Each chapter either implicitly or explicitly suggests what should be done in the future and the theme of 'discretion and power' is also common throughout a number of chapters (p.421). Due to its broad scope it is best placed as an introductory text for students, practitioners and academics interested in this topic.

This collection of essays does what it sets out to do. It sheds light on the underresearched and hitherto ignored world of prison staff: the so-called 'invisible ghosts of penality' (Liebling, 2000: 337).Overall, Understanding Prison Staff provides a longawaited insight into the lives of those individuals who work within the prison confines and is thus a welcome addition to criminal justice, criminology, sociology and the study of work, employment and organisations.

Liebling, A. (2000)'Prison Officers, Policing and the Use of Discretion', Theoretical Criminology, 3(2): 173-87. 